\title{
THE INTERLEUKIN-1 $\beta$-MEDIATED REGULATION OF PROENKEPHALIN AND OPIOID RECEPTOR MESSENGER RNA IN PRIMARY ASTROCYTE-ENRICHED CULTURES
}

\author{
B. B. RUZICKA* and H. AKIL \\ Mental Health Research Institute, University of Michigan, 205 Zina Pitcher Place,, Ann Arbor, MI, \\ 48109-0720, U.S.A.
}

\begin{abstract}
Opioids have been found to modulate the function of the immune system by regulating the biochemical and proliferative properties of its cellular components. The interaction of opioid and immune systems, however, is not unidirectional, but rather, bidirectional in nature. In the CNS, one cellular target of immune system activation is the astrocytes, glial cells known to synthesize proenkephalin. We have recently shown that these cells also express the messenger RNA transcripts for the opioid receptors $\mu, \delta$ and $\kappa$, raising the question of the functional significance of this opioid peptide and the related receptors in the astrocytes. That is, why do astrocytes express proenkephalin and opioid receptors, and are these molecules responsive to a factor to which the astrocytes could be exposed in vivo? Furthermore, do these molecules respond to this factor in a region-specific fashion? In the present study, in order to characterize the astrocytic opioid response to an immune factor, we examined the concomitant regulation of $\mu, \delta, \kappa$ and proenkephalin messenger RNAs by interleukin- $1 \beta(1 \mathrm{ng} / \mathrm{ml}=60 \mathrm{pM}, 24 \mathrm{~h})$ in primary astrocyte-enriched cultures derived from the rat (post-natal day 1-2) cortex, striatum, cerebellum, hippocampus and hypothalamus. Interleukin- $1 \beta$ treatment was found to increase by $55-75 \%$ the level of $\mu$ receptor messenger RNA in striatal, cerebellar and hippocampal cultures, but not in cultures derived from the cortex or hypothalamus. However, the cytokine had no effect on the level of $\delta$ receptor messenger RNA in any of the five cultures examined. In marked contrast to its stimulatory effects on $\mu$ receptor messenger RNA levels and its lack of an effect on $\delta$ receptor messenger RNA expression, interleukin- $1 \beta$ reduced to $10-30 \%$ of control levels the $\kappa$ receptor messenger RNA levels in all cultures. Interleukin- $1 \beta$ had no effect on the level of proenkephalin messenger RNA in cortical, striatal, cerebellar and hypothalamic cultures, but did significantly decrease the expression of proenkephalin messenger RNA in hippocampal cultures to $40 \%$ of the control level. Therefore, interleukin- $1 \beta$ differentially regulated opioid receptor messenger RNA in astrocyte-enriched cultures in a manner dependent upon both the receptor type and the brain region from which the culture was derived. The cytokine also differentially regulated proenkephalin messenger RNA in a region-dependent fashion.

These findings suggest a capacity for astrocytes to differentially regulate opioid peptide and receptor messenger RNAs in response to an immune factor, supporting the potential existence of a novel immune-opioid system interaction in the CNS. (C) 1997 IBRO. Published by Elsevier Science Ltd.
\end{abstract}

Key words: astrocytes, proenkephalin, opioid receptors, interleukin- $1 \beta$, immune-opioid interactions.

Opiates, such as morphine and heroin, exert their many physiological effects by mimicking the actions of the endogenous opioid peptides, endorphins, dynorphins and enkephalins. The mechanism of opiate and opioid peptide action involves the activation of one or more opioid receptor types, generally classified as $\mu, \delta$ or $\kappa .{ }^{15}$ The activation of the individual opioid receptor types often produces different physiological responses, due, in part, to their distinct anatomical localizations. Historically, it was presumed that opioid peptides and receptors had a

*To whom correspondence should be addressed at: Bayer Corp., Pharmaceutical Division, 400 Morgan Lane, West Haven, CT 06516, U.S.A. (present address).

Abbreviations: BSA, bovine serum albumin; EDTA, ethylenediaminetetra-acetate; EMEM, Eagle's minimum essential medium; IEG, immediate-early gene; IL, interleukin; POMC, proopiomelanocortin; SDS, sodium dodecyl sulphate; SSC, standard saline citrate. purely neuronal localization. However, much evidence has recently accumulated to support a nonneuronal localization for these molecules. As such, opioid peptides, ${ }^{27,35}$ as well as classical and nonclassical opioid receptors ${ }^{12,18,33}$ have been localized to cells of the immune system.

There is now ample scientific support for an opioid-mediated regulation of the immune system. $^{7,26}$ Morphine, as well as endogenous opioid peptides such as methionine-enkephalin, have been shown to influence the function of the immune system by modulating the activity of its various cellular components. In this regard, opioids have been found to alter the proliferative and biochemical properties of macrophages, $\mathrm{B}$ and $\mathrm{T}$ lymphocytes, natural killer cells, polymorphonuclear leukocytes, microglia and astrocytes. $^{10,32}$ However, the interaction between opioid and immune systems is not unidirectional, but rather, reciprocal in nature. Therefore, not only do 
opioids regulate the function of the immune system, but immune factors also appear to modulate the function of certain opioidergic systems. Perhaps one of the best characterized immune factor-opioid system interactions is the interleukin-1 $\beta$ (IL-1 $\beta$ )mediated regulation of the pituitary pro-opiomelanocortin (POMC) system. The pituitary POMC system is a major component of the hypothalamicpituitary-adrenal axis which is activated in response to stress. IL-1 $\beta$, a cytokine involved in the acute phase of the immune response, has been found to augment the expression of POMC $\mathrm{mRNA}^{8}$ and to enhance the secretion of the POMC-derived peptide, $\beta$-endorphin, in cultured pituitary cells. ${ }^{2,5,14,22}$ In vivo, endotoxin treatment, ${ }^{9}$ Newcastle Disease Virus inoculation $^{6}$ and IL-1 $\beta$ administration ${ }^{4}$ have been shown to stimulate the pituitary POMC system, resulting in the release of $\beta$-endorphin as well as another POMC-derived peptide, adrenocorticotropin hormone. Interestingly, both in vitro and in vivo, activation of the pituitary POMC system by the cytokine elicits an opioid response which is distinct from that evoked upon exposure to stress, suggesting that this opioid system may be differentially regulated by stress and immune system activation. ${ }^{3,22}$

In contrast to the well-characterized interaction between the immune and pituitary POMC systems, the interaction between the immune and dynorphin systems have not been well-studied. However, some provocative data concerning the IL-1 $\beta$-mediated regulation of opioid peptide secretion from immune cells within inflamed tissue suggests the possibility of at least one such interaction. Schafer et al. ${ }^{25}$ have described the release of dynorphin A from immune cells in inflamed tissue in response to IL-1 $\beta$. Furthermore, these authors have postulated that the IL-1 $\beta$ induced liberation of dynorphin A from macrophages and lymphocytes within such tissue may result in the interaction of the dynorphin A with opioid receptors on nociceptive nerve terminals, producing an observable, localized analgesia. Therefore, the initiation of a peripheral immune response may also result in the secretion of opioid peptides and a subsequent analgesic response.

In the CNS, a major target of immune system activation is the astrocytes, glial cells which are activated under conditions of CNS infection, trauma or injury, and which respond to the elevated IL-1 $\beta$ under such conditions with a dramatic proliferation response. Interestingly, astrocytes have been shown, both in vitro and in vivo, to synthesize the opioid peptide precursor, proenkephalin. ${ }^{17,28}$ However, these cells apparently do not produce POMC-derived or dynorphin-related peptides. Like those immune cells in inflamed tissue, astrocytes also appear to respond to IL-1 $\beta$ with an altered opioid peptide expression: IL-1 $\beta$ has been found to modulate the proenkephalin mRNA expression level in cultured astrocytes. ${ }^{19,20}$ We have recently described the differential expression by primary astrocyte-enriched cul- tures of the mRNA species for the three opioid receptor types, $\mu, \delta$ and $\kappa^{23}$ The observation that astrocytes synthesize proenkephalin, together with the findings that $\mu, \delta$ and $\kappa$ mRNA species were expressed at different levels within a particular culture, and were also characterized by distinct distribution profiles across different astrocyte-enriched cultures, raised the question of the functional significance of these molecules within the astrocytes. That is, why do astrocytes express the proenkephalin peptide and opioid receptors? Are these molecules responsive to a factor to which the astrocytes may conceivably be exposed in vivo? Moreover, would this responsiveness be region specific? In a preliminary study, we demonstrated that IL- $1 \beta$ regulated the $\mu$ receptor mRNA expression in astrocyte-enriched cultures. $^{24}$ These data suggested a possible immune factor-opioid system (peptide and receptor) interaction in astrocytes. However, the effects of this cytokine on the concomitant expression of the astroglial proenkephalin, $\mu, \delta$ and $\kappa$ mRNAs remained unknown. In the current study, we have investigated the effects of IL-1 $\beta$ on the levels of opioid peptide and receptor mRNAs in astrocyte-enriched cultures established from five different rat brain regions: the cortex, striatum, cerebellum, hippocampus and hypothalamus.

\section{EXPERIMENTAL PROCEDURES}

\section{Chemicals}

All chemicals, unless otherwise stated, were of reagent grade and were obtained from Sigma (St. Louis, MO).

\section{Primary glial cell cultures}

Primary glial cultures were established as described previously. ${ }^{22}$ (Note that in the generation of primary cell cultures, all animal procedures were conducted in accordance with the guidelines set forth by the National Institute of Health for the care and use of laboratory animals. Additionally, all efforts were made to keep animal stress, suffering and discomfort to a minimum, and to reduce whole-animal manipulations to those only absolutely necessary). In brief, the brains of 1- to 2-day-old rat pups (Sprague-Dawley, Charles River) were removed, and the cortex $(\mathrm{Ctx})$, striatum (Str), cerebellum $(\mathrm{Cb})$, hippocampus (Hippo) and hypothalamus (Hypo) dissected. The tissues were chemically dissociated by trypsinization at $37^{\circ} \mathrm{C}$ for $30 \mathrm{~min}$. Following trypsinization, the tissues were mechanically dissociated by trituration in the presence of DNAse and trypsin inhibitor. The resulting cell suspension was centrifuged through a bovine serum albumin (BSA) gradient at $100 \mathrm{~g}$ for $10 \mathrm{~min}$. The cell pellet was resuspended in $3 \mathrm{ml}$ of growth medium (see below) and the cell yield determined by using a hemocytometer.

The cells were seeded at a density of $5 \times 10^{5}$ cells/ $100 \times 20 \mathrm{~mm}$ uncoated culture dish (Sarstedt, Newton, NC) in $5 \mathrm{ml}$ growth medium consisting of Eagles's minimal essential medium (EMEM) with D-valine and Earle's salts (Gibco BRL, Grand Island, New York) and supplemented with glucose and fetal calf serum to final concentrations of $33 \mathrm{mM}$ and $10 \%$, respectively. In addition, the antibiotic gentamicin $(100 \mu \mathrm{g} / \mathrm{ml}$, Gibco BRL) was included in the growth medium.

One day after seeding, the growth medium was replaced with $10 \mathrm{ml}$ ice-cold, supplemented EMEM. Thereafter, the 
cells were maintained by replacing $5 \mathrm{ml}$ of growth medium with ice-cold, supplemented EMEM every three days. These incubation conditions favoured astrocyte proliferation, such that, at confluence (day 10-11 in vitro), greater than $95 \%$ of the cells were astrocytes as determined by immunocytochemistry for glial fibrillary acidic protein. No neurons, as determined by immunocytochemistry for neuron specific enolase, were visualized.

\section{Interleukin-1 $\beta$ treatment}

At confluence (day 10-11 in vitro), cells were incubated in the presence of serum-free EMEM containing IL-1 $\beta(1.0 \mathrm{ng} /$ $\mathrm{ml}=60 \mathrm{pM}$ ) dissolved in $10 \mathrm{mM}$ acetic acid with $0.1 \%$ BSA ( $5 \mu \mathrm{l}$ IL- $1 \beta$ stock added to $500 \mathrm{ml}$ culture medium). Cells exposed to the serum-free EMEM containing only vehicle served as the control cells. Cells were treated with either vehicle alone or IL-1 $\beta$ for $24 \mathrm{~h}$, after which time they were lysed directly on the plates with Trizol reagent (Gibco BRL) to extract total RNA (see below).

\section{$R N A$ extractions}

RNA was extracted from the cells as described previously. ${ }^{22}$ Briefly, Trizol reagent $(4 \mathrm{ml})$ was applied consecutively to two to five plates of cells to extract RNA. RNA was organically extracted from the Trizol reagent by the addition of chloroform $(0.8 \mathrm{ml})$. The RNA in the aqueous phase was then precipitated with isopropanol $(2 \mathrm{ml})$, centrifuged, and the resulting RNA pellet resuspended in sterile water $(300 \mu \mathrm{l})$ and re-precipitated with ethanol $(750 \mu \mathrm{l})$ at $-20^{\circ} \mathrm{C}$. The RNA samples were stored under these precipitation conditions until analysis using solution and dot blot hybridization procedures.

\section{Synthesis of radiolabelled $c R N A$ probes}

To detect and quantify $\mu, \delta$ and $\kappa$ opioid receptor mRNA species, corresponding cRNA probes were synthesized as previously described. ${ }^{22}$ It should be emphasized that the opioid receptor cRNA probes were designed to hybridize to RNA sequences representing distinct receptor domains and characterized by relatively low sequence homologies. Any sequence homology that did exist was only for an abbreviated region, and would generate an extremely short protected fragment that, following hybridization, RNAse treatment and electrophoresis (see sections below), would be readily distinguishable from the fully protected RNA fragment.

The rat proenkephalin cRNA probe was generated from a 693 base-pair SphI-Smal restriction fragment of a proenkephalin cDNA (generous gift of Dr S. Sabol, NIH) subcloned into pGEM3 (Promega, Madison WI).

All probes were labelled using $\left[{ }^{32} \mathrm{P}\right] \mathrm{UTP}$ (ICN) according to the method outlined previously ${ }^{22}$ and resulted in cRNA probes varying in specific activity between 13000 and $50000 \mathrm{Ci} / \mathrm{mmol}$.

To control for variability in the quantities of extracted mRNA, the level of mRNA for cyclophilin-binding protein was used as a marker of total RNA levels. Cyclophilinbinding protein mRNA was detected by probing with $1 \mathrm{~B} 15$ (a generous gift form Dr J. G. Sutcliffe, Research Institute of the Scripps Clinic), a cDNA clone of the rat mRNA encoding this protein

\section{Solution hybridization/ribonuclease (RNase) protection} assays

For the solution and dot blot (see below) hybridizations, each RNA sample was resuspended in $11 \mu \mathrm{l}$ sterile water and aliquoted to yield $9 \mu \mathrm{l}$ and $1 \mu \mathrm{l}$ for the solution and dot blot hybridizations, respectively. Solution hybridizations were employed to detect opioid receptor mRNAs while dot blot hybridizations were used to detect proenkephalin and cyclophilin-binding protein mRNAs. All solution and dot blot hybridizations were always performed concomitantly.
RNase protection assays were performed as detailed in a previous report. ${ }^{22}$ In brief, the assays involved an overnight hybridization with $2 \times 10^{5}$ c.p.m. cRNA probe at $60^{\circ} \mathrm{C}$ followed by an RNase digestion ( $1 \mathrm{~h}$, room temperature), a proteinase $\mathrm{K}$ treatment $\left(30 \mathrm{~min}, 37^{\circ} \mathrm{C}\right)$, an organic extraction and the precipitation in the presence of yeast RNA $(1 \mu \mathrm{g})$ by the addition of ethanol.

\section{Electrophoresis of protected RNA fragments}

RNA pellets were heat-denatured $\left(90^{\circ} \mathrm{C}\right)$ and fractionated on a vertical $4 \%$ polyacrylamide denaturing gel (7 M urea) in $1 \times$ TBE $(89 \mathrm{mM}$ Tris, $89 \mathrm{mM}$ boric acid, $2 \mathrm{mM}$ EDTA). Following electrophoresis, the gel was dried under vacuum $\left(80^{\circ} \mathrm{C}, 60 \mathrm{~min}\right.$ ), and then exposed to X-ray film (Kodak $\mathrm{XAR}$ ) with two enhancer screens at $-80^{\circ} \mathrm{C}$ for a period ranging from $24 \mathrm{~h}$ to seven days.

\section{Dot blot hybridizations}

Proenkephalin and cyclophilin-binding protein mRNA levels were quantified using a dot-blot analysis as described previously. ${ }^{22}$ An aliquot ( $1 \mu \mathrm{l}$ from an $11 \mu$ l volume) of each RNA sample was applied in diluted form, under vacuum, to a Nytran membrane (Schleicher and Schuell, Keene NH) contained within a hybridization manifold and previously rinsed with $10 \times$ standard saline citrate $(\mathrm{SSC} ; 0-3 \mathrm{M} \mathrm{NaCl}$, $0.3 \mathrm{M}$ sodium citrate). The membrane was allowed to air dry for $5 \mathrm{~min}$, and the RNA was fixed to the membrane by UV cross-linking using a Stratagene UV cross-linker.

Following a prehybridization period of $0.5-2 \mathrm{~h}$, the proenkephalin or $1 \mathrm{~B} 15$ probe was added to a final concentration of $1 \times 10^{6}$ c.p.m. $/ \mathrm{ml}$. The membrane was hybridized at $60^{\circ} \mathrm{C}$ for an overnight period in $5 \%$ formamide, $400 \mathrm{mM}$ sodium phosphate (pH 7.2), $1 \mathrm{mM}$ EDTA, BSA ( $1 \mathrm{mg} / \mathrm{ml})$ and $5 \%$ sodium dodecyl sulphate (SDS). After hybridization, the membrane was washed at $70^{\circ} \mathrm{C}$ in $0.1 \times \mathrm{SSC}$ and $0.1 \%$ SDS, and then exposed to X-ray film (Kodak XAR) at room temperature for 1-24 h. Previous studies using Northern blot analysis of astroglial RNA revealed that the $1 \mathrm{~B} 15$ and proenkephalin probes each hybridized to a single RNA species of the expected and apparent molecular weights of 1.2 and $1.4 \mathrm{~kb}$, respectively (data not shown).

\section{Data expression and analysis}

Autoradiogram signals generated from the $\left[{ }^{32} \mathrm{P}\right] \mathrm{cRNA}$ : mRNA hybrids during the solution and dot blot hybridizations were analysed with respect to the intensity of grey level using computerized image analysis (NIH Image). In regard to the solution hybridization, only those signals generated from the appropriately sized protected fragments were analysed. The grey level determined for the signal generated by each protected fragment was corrected for autoradiogram exposure time and probe-specific activity, and standardized with respect to the level of expression of cyclophilin-binding protein. Standardized grey values were then expressed as an IL-1 $\beta$ treatment:control ratio. Results reflect the means \pm S.E.M. of five to 12 values obtained from three to five separate studies, and are presented as a per cent change relative to the control value. Data were analysed using a two-tailed Student's $t$-test. Results were considered statistically significant if $P \leq 0.05$.

\section{RESULTS}

\section{Effects of interleukin-1 $\beta$ on opioid receptor $m R N A$ levels}

Following a $24 \mathrm{~h}$ treatment with IL-1 $\beta$ ( $1 \mathrm{ng} /$ $\mathrm{ml}=60 \mathrm{pM}$ ), the level of $\mu$ receptor mRNA was found to be increased in astrocyte-enriched cultures 
established from the striatum, cerebellum and hippocampus (Fig. 1, Table 1). This increase, which represented an approximate $55-75 \%$ elevation above control $\mu$ receptor mRNA levels, was not observed in the cortical or hypothalamic astrocyte-enriched cultures. Therefore, IL-1 $\beta$ produced a differential upregulation of $\mu$ receptor mRNA in these cultures, confirming the results reported in a preliminary study. $^{24}$

Although IL-1 $\beta$ was found to enhance $\mu$ receptor mRNA expression in some cultures, the cytokine had no apparent effect on the level of $\delta$ receptor mRNA in the five astrocyte-enriched cultures examined (Table 1). A tendency toward an elevated $\delta$ receptor mRNA expression was observed in the striatal astrocyte-enriched cultures, however, the relatively high variability associated with these data reflected an inconsistent response which was statistically insignificant (Fig. 1, Table 1).

In marked contrast to its effects on $\mu$ and $\delta$ receptor mRNA expression, IL-1 $\beta$ produced a dramatic decrease in the level of $\kappa$ receptor mRNA in each of the five glial cultures examined (Table 1). The most modest responses were observed in the cultures established from the cortex and hippocampus, in which $\kappa$ receptor mRNA levels were reduced to approximately $30 \%$ of control levels. The most robust response was observed in the cerebellar cultures, in which the $\kappa$ receptor mRNA was reduced to approximately $10 \%$ of the control level. Cultures generated from the striatum (Fig. 1) and hypothalamus displayed an intermediate sensitivity to the cytokine, respectively, expressing $25 \%$ and $15 \%$ of control $\kappa$ receptor mRNA levels following a $24 \mathrm{~h}$ exposure to the cytokine.

\section{Effects of interleukin-1 $\beta$ on proenkephalin $m R N A$ levels}

To determine whether the IL-1 $\beta$-mediated changes in opioid receptor mRNA expression in the astrocyte-enriched cultures were accompanied by any changes in the expression of the proenekphalin mRNA, a dot blot analysis of RNA was carried out. Table 1 shows that whereas IL-1 $\beta$ had no effect on the level of proenkephalin mRNA in cortical, striatal, cerebellar or hypothalamic cultures, the cytokine did significantly decrease the expression of proenkephalin mRNA in the hippocampal cultures to $40 \%$ of the control level (see also Fig. 1).

\section{Discussion}

In this study, we report for the first time the concomitant regulation of opioid peptide and receptor mRNAs by the cytokine IL-1 $\beta$ in primary astrocyte-enriched cultures. Therefore, not only are proenkephalin and opioid receptors expressed by astrocytes in vitro, but these molecules are responsive to an immune factor to which the astrocytes could potentially be exposed in vivo. Two conclusions are immediately apparent from the results of this study. First, IL-1 $\beta$ differentially regulated the expression of proenkephalin mRNA in a region-dependent fashion. Second, IL-1 $\beta$ also differentially modulated the expression of opioid receptor mRNA in a manner dependent upon both the receptor type and the brain region from which the culture was established.

Our finding that proenkephalin expression in cortical cultures was not altered by IL- $1 \beta$ is at variance with observations reported by Low et al. ${ }^{19}$ and Negro et $a .^{20}$ These groups reported an IL-1 $\beta$-mediated increase in proenkephalin mRNA in cortical astrocyte-enriched cultures. However, the discrepancy between our findings and those described in the above studies may be due to differences in the nature and treatment of the glial cell cultures. While we established primary cortical cultures, Low et al. ${ }^{19}$ utilized a secondary cortical astroglial culture (i.e. a subculture). Moreover, Low et al. ${ }^{19}$ treated the cultures with a 10 -fold greater IL- $1 \beta$ concentration than was employed in our study, whereas Negro et al. ${ }^{20}$ used a cytokine concentration comparable to our own, but for a substantially shorter treatment period ( $4 \mathrm{~h}$ versus $24 \mathrm{~h}$ ). Thus, the manner of the establishment, maintenance and treatment of astrocyteenriched cultures may impact significantly on their responsiveness to the cytokine.

The region-dependent regulation of the opioid peptide and receptor mRNA species by IL-1 $\beta$ suggests a heterogeneity in the sensitivity of these cells to the cytokine. Such a heterogeneity is consistent with previous reports in the literature of regionally-specific astrocytes characterized by unique biochemical and functional profiles. In this regard, astrocytes derived from the cortex, striatum, cerebellum and hippocampus were demonstrated to differ in their capacity for neurotransmitter uptake ${ }^{16}$ and in their responsiveness to vasoactive intestinal peptide. ${ }^{11}$ In the context of these reports, it is then perhaps not surprising that astrocytes also exhibit a difference in their sensitivity to IL- $1 \beta$.

The heterogeneous nature of the astroglial response to IL-1 $\beta$ raises the question of whether the differential sensitivity to the cytokine is the result of a heterogeneous IL-1 $\beta$ receptor expression across the cultures. Although the answer to this question is currently unknown, IL-1 $\beta$ receptors have indeed been localized to astrocytes, ${ }^{1}$ and have also been found to be heterogeneously distributed across brain regions. ${ }^{31}$ However, the relative abundance of IL- $1 \beta$ receptors across cultures may not completely explain the heterogeneous opioid response to IL-1 $\beta$. In this regard, very compelling is the observation that all five astrocyte-enriched cultures responded vigorously to IL-1 $\beta$ with a reduction in the $\kappa$ receptor $m R N A$ level, suggesting that IL-1 $\beta$ receptor abundance alone may not account for the heterogeneous responsiveness of the astroglia to this cytokine. Differences in IL-1 $\beta$ receptor-effector coupling may be an equally import- 


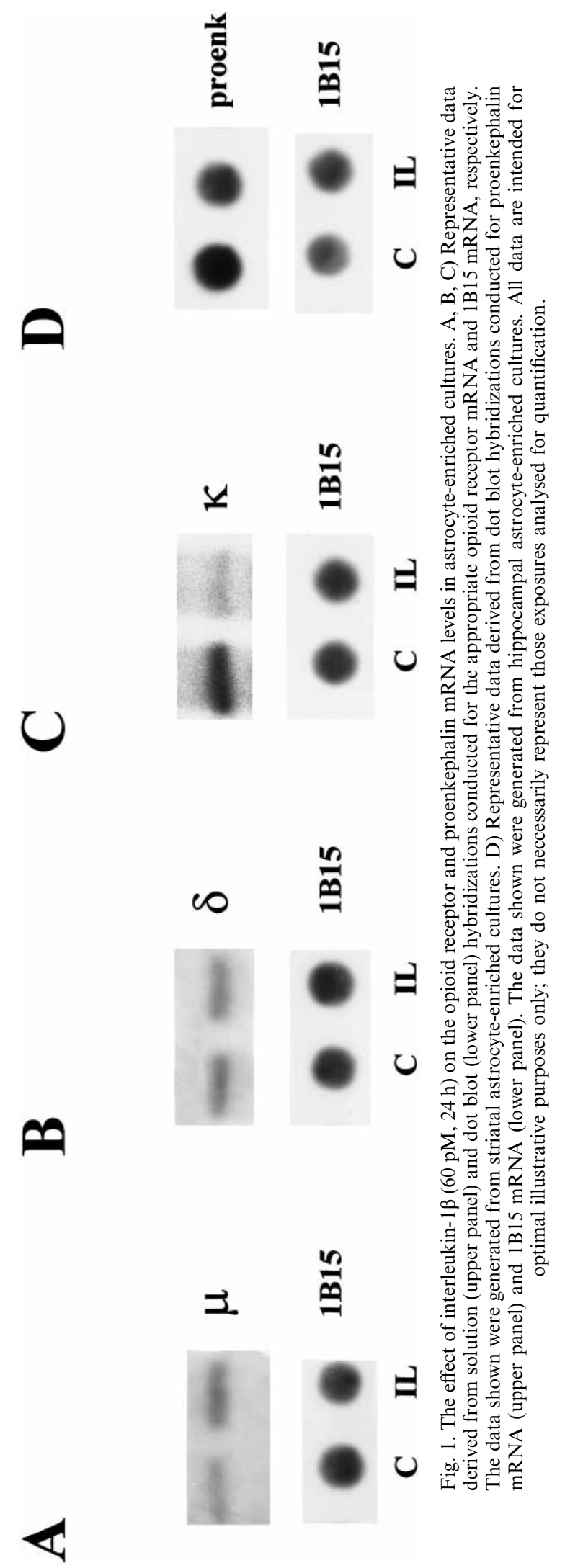


Table 1. The effects of interleukin-1 $\beta(60 \mathrm{pM}, 24 \mathrm{~h})$ on the opioid receptor and proenkephalin mRNA levels

\begin{tabular}{llccc}
\hline & & \multicolumn{2}{c}{ mRNA level (per cent control level) } & \\
& Mu receptor & Delta receptor & Kappa receptor & Proenkephalin \\
\hline Cortex & $112.7 \pm 11.9$ & $81.6 \pm 5.7$ & $32.2 \pm 7.3^{*}$ & $91.6 \pm 9.1$ \\
Striatum & $175.5 \pm 17.0^{*}$ & $165.2 \pm 39.4$ & $24.9 \pm 4.6^{*}$ & $100.5 \pm 8.7$ \\
Cerebellum & $158.0 \pm 17.0^{*}$ & $78.0 \pm 9.1$ & $9.8 \pm 1.9^{*}$ & $88.3 \pm 5.9$ \\
Hippocampus & $152.2 \pm 17.5^{*}$ & $111.1 \pm 5.4$ & $29.5 \pm 10.1^{*}$ & $39.7 \pm 4.9^{*}$ \\
Hypothalamus & $102.9 \pm 3.8$ & $106.7 \pm 10.9$ & $14.9 \pm 4.2^{*}$ & $97.3 \pm 5.0$ \\
\hline
\end{tabular}

The opioid receptor and proenkephalin mRNA levels were standardized with respect to 1B15 expression. The data were then expressed as a per cent of the standardized control level. All values represent the mean \pm S.E.M. of five to 10 observations obtained from two to five separate studies. ${ }^{*} P<0.05$ when compared to the control cells.

ant factor in defining astrocyte heterogeneity in terms of IL-1 $\beta$ sensitivity. Indeed, preliminary data from our laboratory suggest that IL-1 $\beta$ differentially induces immediate-early gene (IEG) expression ( $c$-fos and $c$-jun) in these astrocyte-enriched cultures. The issues of IL-1 $\beta$ receptor abundance and IL-1 $\beta$ receptor-effector coupling await further study.

The mechanism of IL-1 $\beta$ action in eliciting the changes in opioid receptor and peptide mRNAs in these cultures is currently unknown, and is complicated by the fact that the cytokine is capable of activating both astrocytes and microglia, is synthesized and secreted by both cell types, and may have its activity modulated in vivo by soluble IL-1 receptors or an IL-1 receptor antagonist. ${ }^{13,21}$ The astrocyte-enriched cultures established in this study may contain a small proportion of microglia. Thus, the mechanism of IL-1 $\beta$ may involve, at least partially, the activation of microglia and/or the activity of endogenously-derived IL-1 $\beta$. Similarly, the presence of other endogenous biochemicals, such as soluble IL-1 receptor or receptor antagonist, and their potential IL-1 $\beta$-modulating effects, cannot be dismissed. Furthermore, the contribution of physical factors to the mechanism of IL-1 $\beta$ action also requires consideration. In this regard, the level of cell confluence may modulate the degree of astrocytic opioid peptide and receptor expression in response to IL-1 $\beta$, such that sub-confluent cultures may potentially manifest a response profile distinct from that observed with the confluent cultures examined in this study. Thus, the mechanism of IL-1 $\beta$ action in evoking the observed changes in astrocytic opioid peptide and receptor mRNAs may depend greatly on the biochemical and physical characteristics of the culture.

Biochemically, cyclic AMP, prostaglandin $E_{2}$ and $\mathrm{Ca}^{2+}$ have all been implicated as possible intracellular signalling molecules in the actions of IL-1 $\beta .^{13,21}$ In addition, IL-1 $\beta$ has been shown to induce activity of the nuclear factor AP-1 via increases in the expression in $c$-jun mRNA. Consistent with this finding is our observation that IL-1 $\beta$ elicits an induction in both $c$-fos and $c$-jun expression in the astrocyteenriched cultures (unpublished observations), the magnitude of which is dependent upon the brain region from which the culture was established. Interestingly, the $\mu$ receptor and proenkephalin genes, but not the $\delta$ or $\kappa$ receptor genes, contain an AP-1 consensus sequence in the promotor region. Therefore, the mechanism of IL-1 $\beta$ action may involve, but may not be limited to, the expression of IEGs.

Although astrocytes have been demonstrated to express opioid receptors in vivo, ${ }^{30}$ the physiological significance of an IL- $1 \beta$-mediated regulation of the astroglial opioid peptide and receptor mRNAs is unknown, and its understanding is complicated by the fact that the function of astrocytes under normal and pathological conditions is ill-defined. Additionally, the influence of this cytokine on the opioid peptide and receptors at the level of protein expression is also currently unclear. The effects of IL-1 $\beta$ on the remainder of the opioid peptide and receptor biosynthetic pathways await further study. However, the in vitro findings suggest a capacity for astrocytes to differentially regulate opioid peptide and receptor genes in response to an immune factor, supporting the potential existence of a novel immune-opioid system interaction in the CNS.

\section{CONCLUSIONS}

Although the physiological significance of an IL$1 \beta$-mediated regulation of the astroglial opioid peptide and receptor mRNAs is unknown, it is interesting to note that both IL- $1 \beta$ and opioids have been implicated in the modulation of cell proliferation in the CNS. CNS infection, trauma or injury has been shown to enhance IL-1 $\beta$ synthesis and secretion in various immune cells, neurons and astrocytes. ${ }^{13,21}$ The secreted IL-1 $\beta$ produces many effects, including the activation of astrocytes and the stimulation of their proliferation, both of which represent components of a neuroprotective response. ${ }^{13,21}$ Our data suggest that another effect of IL-1 $\beta$ on astrocytes may involve the regulation of opioid receptor expression and enkephalin biosynthesis. Enkephalins have been found to exert anti-mitogenic effects on astrocytes and neurons, ${ }^{29,34}$ as well as to alter the proliferative and operational characteristics of immune cells. ${ }^{10,32}$ Thus, it is intriguing to speculate that the concomitant regulation of proenkephalin and 
opioid receptor mRNA expression by IL-1 $\beta$ in astrocytes may result in a multi-branched regulation of neuroimmune system function. One branch, representing an autocrine component, may reflect a localized effect at the level of the astrocyte, resulting in a modulation of the gliotic response. In this regard, the (regulated) astrocytic opioid receptors may be the targets not only for the enkephalins liberated from the astrocytes themselves, but also for POMCderived or dynorphin-related peptides secreted directly or indirectly from IL-1 $\beta$-responsive cells (neurons?, endocrine cells?) located in the vicinity. A second branch, representing a paracrine component, may reflect a more distant effect on microglia and other immune cells, leading to a modulation of their phagocytic, metabolic and/or proliferative properties. Yet a third branch, representing a distinct paracrine component, may reflect an action on neurons, producing an alteration in neuronal excitability and/or proliferation. Such events may possibly contribute to the regulation of neuropathological processes in the CNS, the exact nature of which would be regionally defined. Therefore, the astroglial opioid system may be important in the IL-1 $\beta$-initiated, co-ordinated response to CNS infection, trauma or injury.

Acknowledgements-This work was supported by NIDA (grants DA 02265 and DA 08920). Additionally, B.B.R. was supported by a post-doctoral fellowship from NIDA (grant T32 DA 07268-05).

\section{REFERENCES}

1. Bam E. M., Sarlieve L. L. and Haour F. G. (1993) Interleukin-1 binding sites on astrocytes. Neuroscience 52, 725-733.

2. Beach J. E., Smallridge R. C., Kinzer C. A., Bernton E. W., Holaday J. W. and Fein H. G. (1988) Rapid release of multiple hormones from rat pituitaries perfused with recombinant interleukin-1. Life Sci. 41, 1-7.

3. Berkenbosch F., de Goeij D. E. C., Del Rey A. and Besedovsky H. O. (1989) Neuroendocrine, sympathetic and metabolic responses induced by interleukin-1. Neuroendocrinology 50, 570-576.

4. Berkenbosch F., Van Oers J., Del Rey A., Tilders F. and Besedovsky H. (1987) Corticotropin-releasing-factorproducing neurons in the rat activated by interleukin-1. Science 238, 504-506.

5. Bernton E. W., Beach J. E., Holaday J. W., Smallridge R. C. and Fein H. G. (1987) Release of multiple hormones by a direct action of interleukin-1 on pituitary cells. Science $\mathbf{2 5 9}, 519-521$.

6. Besedovsky H., Del Rey A., Sorkin E. and Dinarello C. A. (1986) Immunoregulatory feedback between interleukin-1 and glucocorticoid hormones. Science 233, 652-654.

7. Blalock J. E. (1989) A molecular basis for bidirectional communication between the immune and neuroendocrine systems. Physiol. Rev. 69, 1-32.

8. Brown S. L., Smith L. R. and Blalock J. E. (1987) Interleukin 1 and Interleukin 2 enhance proopiomelanocortin gene expression in pituitary cells. J. Immunol. 139, 3181-3183.

9. Carr D. B., Bergland R., Hamilton A., Blume H., Kasting N., Amold M., Martin J. B. and Rosenblatt M. (1982) Endotoxin-stimulated opioid peptide secretion: two secretary pools and feedback control in vivo. Science 217, $845-848$.

10. Chang K.-J. (1984) Opioid peptides have actions on the immune system. Trends Neurosci. 7, 234-235.

11. Cholewinski A. J. and Wilkin G. P. (1988) Astrocytes from forebrain, cerebellum and spinal cord differ in their responses to vasoactive intestinal peptide. J. Neurochem. 51, 1626-1633.

12. Chuang L. F., Chuang T. K., Killam K. F., Chuang A. J., Kung H.-F., Yu L. and Chuang R. Y. (1994) Delta opioid receptor gene expression in lymphocytes. Biochem. biophys. Res. Commun. 202, 1291-1299.

13. Dinarello C. A. (1991) Interleukin-1 and Interleukin-1 antagonism. Blood 77, 1627-1652.

14. Fagarasan M. O., Eskay R. and Axelrod J. (1989) Interleukin-1 potentiates the secretion of $\beta$-endorphin induced by secretagogues in a mouse pituitary cell line (AtT20). Proc. natn. Acad. Sci. U.S.A. 86, 2070-2073.

15. Goldstein A. (1987) Binding selectivity profiles for ligands of multiple receptor types: focus on opioid receptors. Trends pharmac. Sci. 8, 114-118.

16. Hansson E. (1983) Accumulation of putative amino acid neurotransmitters, monoamines and D-Ala2-Metenkephalinamide in primary astroglial cultures from various brain areas, visualized by autoradiography. Brain Res. 289, 189-196.

17. Hauser K. F., Osborne J. G., Stiene-Martin A. and Melner M. H. (1990) Cellular localization of proenkephalin mRNA and enkephalin peptide products in cultured astrocytes. Brain Res. 522, 347-353.

18. Hazum E., Chang K.-J. and Cuatrecasas P. (1979) Specific non-opiate receptors for $\beta$-endorphin. Science 205, $1033-1035$.

19. Low K. G., Allen R. G. and Melner M. H. (1992) Differential regulation of proenkephalin expression in astrocytes by cytokines. Endocrinology 131, 1908-1914.

20. Negro A., Tavella A., Facci L., Callegaro L. and Skaper S. D. (1992) Interleukin-1 $\beta$ regulates proenkephalin gene expression in astrocytes cultured from rat cortex. Glia 6, 206-212.

21. Rothwell N. J. (1991) Functions and mechanisms of interleukin-1 in the brain. Trends pharmac. Sci. 12, 430-436.

22. Ruzicka B. B. and Akil H. (1995) Differential cellular regulation of proopiomelanocortin by interleukin-1 $\beta$ and corticotropin releasing hormone. Neuroendocrinology 61, 136-151.

23. Ruzicka B. B., Fox C. A., Thompson R. C., Meng F., Watson S. J. and Akil H. (1995) Primary astroglial cultures derived from several rat brain regions differentially express $\mu, \delta$ and $\kappa$ opioid receptor mRNA. Molec. Brain Res. 34, 209-220.

24. Ruzicka B. B., Thompson R. C., Watson S. J. and Akil H. (1996) Interleukin-1 $\beta$-mediated regulation of $\mu$ opioid receptor mRNA in primary astrocyte-enriched cultures. J. Neurochem. 66, 425-428.

25. Schafer M., Carter L. and Stein C. (1994) Interleukin-1 $\beta$ and corticotropin releasing factor inhibit pain by releasing opioids from immune cells in inflamed tissue. Proc. natn. Acad. Sci. U.S. A. 91, 4219-4223. 
26. Sibinga N. E. S. and Goldstein A. (1988) Opioid peptides and opioid receptors in cells of the immune system. A. Rev. Immunol. 6, 219-249.

27. Smith E. M. and Blalock J. E. (1981) Human lymphocyte production of corticotropin and endorphin-like substances: association with leukocyte interferon. Proc. natn. Acad. Sci. U.S.A. 78, 7530-7534.

28. Spruce B. A., Curtis R., Wilkin G. P. and Glover D. M. (1990) A neuropeptide precursor in cerebellum: proenkephalin exists in subpopulations of both neurons and astrocytes. Eur. molec. Biol. Org. J. 9, 1787-1795.

29. Stiene-Martin A. and Hauser K. F. (1991) Glial growth is regulated by agonists selective for multiple opioid receptor types in vitro. J. Neurosci. Res. 29, 538-548.

30. Svingos A. L., Cheng P. Y., Clarke C. L., Inturrisi C. E., Jenab S. and Pickel V. M. (1994) Topographical distribution and synaptic localization of $\delta$ opiate receptor immunoreactivity in rat prefrontal cortex. Regul. Pept. 54, $291-292$.

31. Takao T., Tracey D. E., Mitchell M. and DeSouza E. B. (1990) Interleukin-1 receptors in mouse brain characterization and neuronal localization. Endocrinology 127, 3070-3078.

32. Teschemacher H., Koch G., Scheffler H., Hildebrand A. and Brantl V. (1990) Opioid peptides: immunological significance?. Ann. N.Y. Acad. Sci. 594, 66-77.

33. Wybran J., Appelboom T., Fanaey J.-P. and Govorts A. (1979) Suggestive evidence for receptors for morphine and methionine-enkephalin on normal human blood T lymphocytes. J. Immunol. 123, 1068-1070.

34. Zagon I. S. and McLaughlin P. J. (1991) Identification of opioid peptides regulating proliferation of neurons and glia in the developing nervous system. Brain Res. 542, 318-323.

35. Zurawski G., Benedik M., Kamb B. J., Abrams J. S., Zurawski S. M. and Lee F. D. (1986) Activation of mouse T-helper cells induces abundant proenkephalin mRNA synthesis. Science 232, 772-775.

(Accepted 28 November 1996) 